\title{
Exploring Insights of Battisa: A Polyherbal Formulation Used During Postpartum Care
}

\author{
Shristi Kumari ${ }^{1}$, A.S. Khalkho ${ }^{1}$ \\ ${ }^{1}$ Department of Biotechnology, Marwari College Ranchi, Jharkhand, India. \\ Corresponding Author: Shristi Kumari
}

DOI: https://doi.org/10.52403/ijhsr.20220213

\begin{abstract}
Post-partum period is known to play vital role from recovery point of view for both the mother and its new born. In general, postpartum period duration is 40 to 60 days. This phase is associated with various physical and mental complications in allopathic treatment. The use of different allopathic medicines to target in some patients results in the origin of various side effects as well as causing financial burden for family also. Over the past decades India is always rich in folk herbal medicines. After, child birth mother is supposed to follow various dietary as well as behavioral restriction. Postpartum mother is restricted to eat cold food stuffs and food stuffs such as nuts as well as clarified butter is increased. An herbal formulation of Battisa is given which consists of 32 different herbs and spices which targets most of the physical and mental problems associated with this phase. But, due to more inclination of people towards allopathic medicine gradually traditional knowledge of herbal formulations used is vanishing. So, our research focuses highlighting this study in order to do the preliminary Phytochemical analysis of battisa. Thus, resulting wide knowledge transmission and prospects of its herbal formulations and their futuristic applications during postpartum period to next generation.
\end{abstract}

Key Words: Battisa, polyherbal formulation, postpartum care, folk herbal medicine.

\section{INTRODUCTION}

Giving birth to a new-born is always considered as the most important celebrational events in the journey of woman's life. It is the time period of auspicious and social celebration in various societies. ${ }^{1}$ During this phase of child birth woman has to undergo various transitional stages from physical, mental and hormonal. The phases of childbirth are medically subcategorized as pre-delivery period, delivery period and postpartum period. All the phases are to be monitored and are very important considering women's health. In various countries including south east Asian cultures, postpartum period is also considered important point resulting in recovery of woman health by offering a time period of 10-45 days.
The postpartum period (women's health recovery post delivery) is broadly categorized as beginning of 01 hour after delivery of the placenta and terminating till 6 weeks. $^{2}$ It is marked as a critical period for mother as well as new born. ${ }^{3}$ This phase shows tremendous changes, increased health problems subjecting both mother and child into a vulnerable state. Confinement period is the period immediately after delivery in which women and new born is confined to specific area and she need to follow restrictions regarding diet and other behaviours. ${ }^{4}$ It is associated with physical as well as mental complications and also emotional changes. ${ }^{5}$

The World Health Organization (WHO), 2006 also acknowledged that this keeping up with traditional practices in 
various cultures where a 40 day duration period of extra support system provided for the new mother and her baby. However, little proofs are available to backup the timing and content of the postpartum visit, ${ }^{6}$ but still there is evidence that this is a high time period of increased health attention for both mother and new born. Humoral medicinal research revealed that pregnancy marked under hot state while with parturition loss of heat is observed resulting into woman excess of heat loss leading to cold state. Thus, postpartum period extra care should be taken in order to maintain temperature equilibrium state in mother. ${ }^{7}$ The commonly encountered side effects of new mother during early postpartum period (06-07 months) are pain in low uterine caesarean section (LUCS), sexual problems, mastitis, hemorrhoids, wounds, bowel problems, urinary inconsistency, upper respiratory trac infections (URTI), relationship with partner. ${ }^{8}$ Precautionary confinement is necessary for newly born baby and its mother from various illness, as they are highly susceptible and in vulnerable state after child birth. ${ }^{9}$ However, standard treatment procedure under postpartum condition involves proper hygiene, standard nutritional foods, hot food, restriction in household works, avoiding sexual activities etc. Indian traditional culture from past decades offers these therapeutic courses under postpartum period for safety of mother and her newborn. Indian approach of medicine for postpartum condition also includes adapting specialized life style and nutritional food habits for mother upto 45 days of post delivery.

Herbal plants with various medicinal properties play significant role during pregnancy, child birth and postpartum periods across the globe. The cultural revolution including depletion and degradation of traditional medicinal knowledge and also leading into diversity in methodologies of primary health care system. ${ }^{10}$ But still use of herbal medicine is prevailing and growing in various parts of world. In India also herbal medicinal compositions widely used with a composition of 32 herbs known as battisa (local name). The components of battisa are capable of targeting one or multiple complications associated with post partum period. In our research article we are focusing its composition along with backing up with biochemical tests in order to explore its beneficial impact on mother and its new born during postpartum period.

\section{MATERIALS AND METHODS 1. Sample preparation}

The research on herbal medicinal composition battisa was conducted at center of Biotechnology, Marwari college, Ranchi, Jharkhand, India during November, 2020. The battisa powder was prepared by preparing a mixture composition of 32 herbs and grinding it in mortar and pestle.

\section{Extract preparation}

Battisa powder was subjected to the extraction. Both aqueous and organic extract was prepared separately. It involved isolation of compound majority of secondary metabolites for the solvent preparation using the solvent extraction method. ${ }^{11,12}$ Dried battisa powder was taken in a ratio (1g:20ml) in an amber coloured glass container with air tight lid cap. The container was kept at the room temperature for 04 days and shaken frequently. After 04 days liquid was filtered by using filter paper.

\section{Preliminary Phytochemical based quantitative screening-}

Qualitative based photochemical screening of both aqueous as well as methanolic extracts was carried out for the checking of essential nutritional compounds and antioxidants such as- alkaloids, flavonoids, glycoside, saponin, carbohydrate, terpenoids, saponin, tannin, steroids and phytosterols, amino acids and proteins. The screening was carried out using the standard phytochemical experimental procedure. ${ }^{13}$ 


\subsection{Alkaloids Test:-}

(Mayer's \& Wanger's Test)- Total $1 \mathrm{ml}$ of Battisa sample with both the extracts (aqueous and methanolic) and a few drops of Mayer's reagent were added. Similarly, another test Wanger's test was also carried out with same concentration composition of $1 \mathrm{ml}$ of extract $2 \mathrm{ml}$ Wanger's reagent was added.

\subsection{Flavonoids Test :-}

For flavonoids test three different phytochemical tests like alkaline reagent test, ferric chloride test, Shinoda test were carried out for cross validation. Under alkaline test $1 \mathrm{ml}$ of sample extracts (aqueous and methanolic) was treated with 5-10 drops of $20 \%$ ammonium hydroxide solution. In ferric chloride test $2 \mathrm{ml}$ of sample extracts (aqueous and methanolic) with few drops of $10 \%$ Ferric chloride solution were added. While in Shinoda test the sample extracts (aqueous and methanolic) with trace magnesium salts and few drops of concentrated $\mathrm{HCl}$ were added and it was boiled for 5 minutes.

\subsection{Glycosides test:-}

Keller Kiliani test with $1 \mathrm{ml}$ of sample extracts (aqueous and methanolic) were treated with $1 \mathrm{ml}$ of glacial acetic acid and 2-3 drops of 5\% aqueous Ferric chloride solution. To this mixture $0.5 \mathrm{ml}$ of concentrated sulfuric acid was added. While in legal test $2 \mathrm{ml}$ of sample extracts, $1 \mathrm{ml}$ of pyridine and $1 \mathrm{ml}$ of sodium nitroprusside were added. Another Bontrager test was conducted where the test tube of $2 \mathrm{ml}$ of extracts were treated with $2 \mathrm{ml}$ of dilute sulfuric acid and it was boiled for 5 minutes and filtered .To the filtrates equal volume of chloroform was added and mixed well.

\subsection{Test for Saponin: -}

Foam test for saponin presence or absence was carried out with $1 \mathrm{ml}$ of sample extracts and $5 \mathrm{ml}$ of distilled water followed by shaken rigorously.

\subsection{Phenols Test:-}

Ferric chloride test for the exploration of phenol was conducted with $1 \mathrm{ml}$ of sample extracts and 5-6 drops 5\% aqueous Ferric chloride solution.

\subsection{Tannin Test:-}

Braymer's test with $1 \mathrm{ml}$ of sample extracts for was treated with $1 \mathrm{ml}$ of $10 \%$ alcoholic Ferric chloride solution. Similarly, Lead acetate test and Gelatin test were also carried out for dual confirmation of tannin presence test. Under Lead acetate test $1 \mathrm{ml}$ extracts sample were mixed with $10 \%$ lead acetate solution while in Gelatin test the extracts were mixed with $1 \%$ gelatin containing $10 \% \mathrm{NaCl}$.

\subsection{Test for steroids and phytosterols: -} Liebermann-Burchard test with $2 \mathrm{ml}$ of test solution 10 drops of acetic anhydride was added and mixed well. To this $5 \mathrm{ml}$ of concentrated sulfuric acid was added from the sides of the tube. Also, Salkowski test (Sulphuric acid test) was conducted for steroids presence or absence. Under this test along the sides of test tube containing $2 \mathrm{ml}$ sample extracts with $2 \mathrm{ml}$ of chloroform and $3 \mathrm{ml}$ of concentrated sulfuric acid was added.

\subsection{Test for amino acids and proteins:-}

Ninhydrin test for amino acids and proteins were carried out with $1 \mathrm{ml}$ of sample extracts and 2-5 drops of Ninhydrin solution. It was kept on boiling water bath for 1 to 2 minutes under standard lab conditions.

\section{RESULTS}

India has a very rich source in herbal plants. During our research we extracted battisa, a poly herbal composition successfully which is used as best source for treatment and naturally based dietary care supplements for mother and new born during postpartum period. The detail about essential components of battisa are represented in Table 1. 
Shristi Kumari et.al. Exploring insights of battisa: a polyherbal formulation used during postpartum care.

Table 1. The essential components of Battisa

\begin{tabular}{|c|c|c|c|c|}
\hline Local name & Botanical name & Family & Part used & Pharmaceutical effect/s \\
\hline 1. Harshringer & $\begin{array}{l}\text { Nyctanthes arbor-tristis } \\
\text { L. }\end{array}$ & Oleaceae & Bark powder & Analgesic, antipyretic and anti inflammatory \\
\hline 2. Methi & $\begin{array}{l}\text { Trigonella foenum- } \\
\text { graecum }\end{array}$ & Fabaceae & Seed & $\begin{array}{l}\text { Relief from anemia, anti inflammatory, } \\
\text { galagogue }\end{array}$ \\
\hline 3. Nagkeshar & Mesua ferrea & Calophyllaceae & Seed & Anti inflammatory, anti pyretic \\
\hline 4. Ajwain & Trachyspermum ammi & Apiaceae & Seed & Good for indigestion \\
\hline 5. Haldi & Curcuma longa $L$. & Zingiberaceae & Rhizome & Antioxidant, anti inflammatory \\
\hline 6. Shankhpushpi & Convolvulus pluricaulis & Convolvulaceae & Whole plant & Analgesic \\
\hline 7. Mangraila & Nigella sativa $L$. & Ranunculaceae & Seed & Galactagogue and antacid \\
\hline 8. Sauth & $\begin{array}{l}\text { Zngiberaceae officinale } \\
\text { (Roscoe.) }\end{array}$ & Zingiberaceae & Rhizome & Anti inflammatory and anti septic \\
\hline 9. Tejpatta & Cinnamomum tamala & Lauraceae & Dried leaf & Relief from anemia, anti oxidant \\
\hline 10. vanshlochan & Bambusa arundinacea & Bambusaceae & Resin & $\begin{array}{l}\text { Blood purifier, regulates menstrual cycle, pro } \\
\text { biotics }\end{array}$ \\
\hline 11. Bel & Aegle marmelos & Rutaceae & Fruit & Laxative, antioxidant \\
\hline 12. Kush & $\begin{array}{l}\text { Desmostachyabipinnata } \\
\text { L. }\end{array}$ & Cannabaceae & Dried flower & Pain relief \\
\hline 13. Marich & Piper nigrum & Piperaceae & Dried seed & antioxidant \\
\hline 14. Atamgupta & Mucuna pruriens & Fabaceae & Fruit & Antioxidant \\
\hline 15. Pipli & Piper longum & Piperaceae & Fruit & Antioxidant \\
\hline 16. Amala & Phyllanthus embica & Phyllanthaceae & Dried fruit & Astringent and antacid \\
\hline 17. Arjun & Terminalia arjuna $($ Roxb $)$ & Solanaceae & Root powder & $\begin{array}{l}\text { Used to ease anxiety, insomnia and mild } \\
\text { depression and general health promoting factors }\end{array}$ \\
\hline 18. Bhringraaj & Eclipta prostrata & Asteraceae & Whole plant & Antioxidant \\
\hline 19. Dalchini & Cinnamomum verum & Lauralus & $\begin{array}{l}\text { Inner bark } \\
\text { powder }\end{array}$ & Antioxidant and anti inflammatory \\
\hline 20. Harro & Terminalia chebula & Combretaceae & Fruit & Antioxidant \\
\hline 21. Jira & Cuminum cyminum & Apiales & Seed & $\begin{array}{l}\text { Cleanses and detoxifies uterus and also } \\
\text { galactagoue }\end{array}$ \\
\hline 22. Satavar & $\begin{array}{l}\text { Asparagus recemosus } \\
\text { (Wild) }\end{array}$ & Asperagaceae & $\begin{array}{l}\text { Root and } \\
\text { whole plant }\end{array}$ & 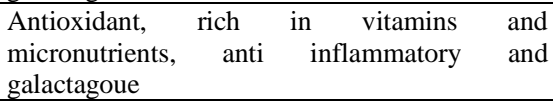 \\
\hline 23. Ghritkumai & Aloe barbadensis Miller. & Asphodelaceae & Root powder & Antioxidant and laxative \\
\hline 24. Bahera & Terminalia bellirica & Combretaceae & Dried fruit & Stringent, laxative and anti inflammatory \\
\hline 25. Palash & $\begin{array}{l}\text { Butea monosperma } \\
\text { (Lam) Taub. }\end{array}$ & Fabaceae & Root & $\begin{array}{l}\text { Tonic, stringent, anti inflammatory, regulates } \\
\text { menstrual flow after childbirth }\end{array}$ \\
\hline 26. Shwet tulsi & Ocimum tenuiflorum $L$. & $\begin{array}{ll}\text { Lamia } & \text { Wanger's } \\
\text { Test les } & \end{array}$ & Dried flower & $\begin{array}{l}\text { Maintain normal level f stress hormone, anti } \\
\text { inflammatory }\end{array}$ \\
\hline 27. Laung & Syzygium aromaticum $L$. & Myrtales & $\begin{array}{l}\text { Dried flower } \\
\text { bud }\end{array}$ & $\begin{array}{l}\text { Antioxidant, antiseptic, anti inflammatory and } \\
\text { anti pyretic }\end{array}$ \\
\hline 28. Saunf & Foeniculum vulgare & Apiaceae & Dried seed & $\begin{array}{l}\text { Laxative, increase formation of new cells and } \\
\text { tissues of breast, antioxidant }\end{array}$ \\
\hline 29. Chhoti elaichi & Elttaria cardamomum $L$. & Zingiberaceae & Dried seed & $\begin{array}{l}\text { Rich souece of vitamin and micronutrients, } \\
\text { antidepressant, protection from UTI }\end{array}$ \\
\hline 30. Baddi elaichi & subulatum & Zingiberales & Dried seed & Anti inflammatory and analgesic \\
\hline 31. Ashwagandha & $\left.\begin{array}{l}\text { Withania } \\
\text { (Dunal.) }\end{array}\right)$ & Solanaceae & Root powder & $\begin{array}{l}\text { Useful to ease anxiety, insomnia and other } \\
\text { health promoting factors }\end{array}$ \\
\hline 32. Jaiphal & $\begin{array}{l}\text { Myristica fragrans } \\
\text { (Houtt.) }\end{array}$ & Myristicaceae & Dried seed & $\begin{array}{l}\text { Useful to induce sleep and calms mind and also } \\
\text { good to relieve depression }\end{array}$ \\
\hline
\end{tabular}

Further, in order to explore the essential components of battisa the samples were extracted in two different solutions aqueous and methanol. The physical appearance of both the extracts of aqueous base and methanolic base were dark yellow and yellow as shown in Table 2 and Figure 2.

Table 2: physical appearance of aqueous and methanolic extract

\begin{tabular}{|l|l|l|}
\hline S.No. & Extract (solvent type) & Colour of extract \\
\hline 1 & Aqueous & Dark yellow \\
\hline 2 & Methanolic & Yellow \\
\hline
\end{tabular}

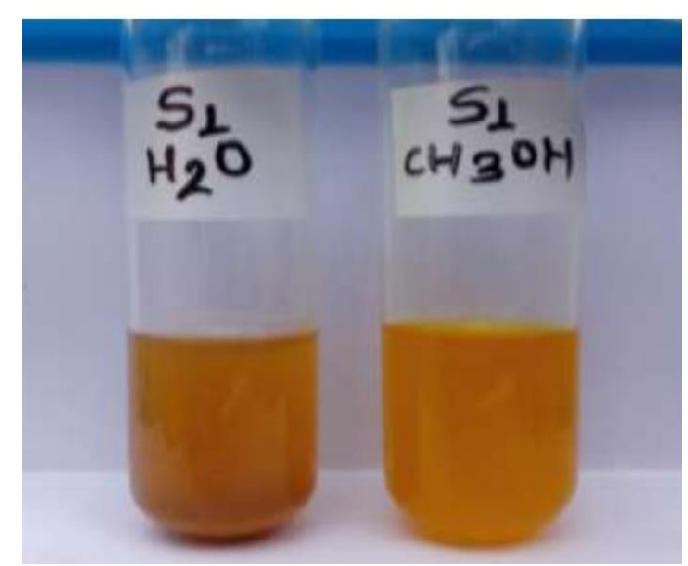

Figure2: The physical appearance of aqueous and methanolic extract as dark yellow and yellow. 
The qualitative screening for aqueous and methanolic extract was carried out using phytochemical screening based approach based on multiple tests. The Mayer's test for identification of alkaloid resulted in cream coloured precipitation indicated the presence of alkaloid. While Wanger's test showed the formation of reddish-brown precipitate thus, indicated the presence of alkaloids. Similarly, under the alkaline test it produced intense yellow and ferric chloride test resulted in green blue colouration indicated the presence of flavonoids. Also Shinoda test also showed positive results indicating the red, pink to orange colouration confirming the presence of flavonoids as shown in Table 3 and Figure 3.

\begin{tabular}{|c|c|c|c|}
\hline \multirow[t]{2}{*}{ TEST FOR } & \multirow[t]{2}{*}{ POSITIVE OBSERVATION } & \multicolumn{2}{|l|}{ SAMPLE 1 } \\
\hline & & $\begin{array}{l}\text { Aqueous Extract } \\
\left(\mathrm{H}_{2} \mathrm{O}\right)\end{array}$ & $\begin{array}{l}\text { Methanol Extract } \\
\left(\mathrm{CH}_{3} \mathrm{OH}\right)\end{array}$ \\
\hline \multicolumn{4}{|l|}{ ALKALOIDS } \\
\hline Mayer's Test & White/cream coloration or precipitation & $\begin{array}{l}\text { Positive } \\
+\end{array}$ & Negative \\
\hline Wagner's Test & Reddish brown coloration/precipitation & $\begin{array}{l}\text { Positive } \\
+\end{array}$ & $\begin{array}{l}\text { Negative } \\
-\end{array}$ \\
\hline \multicolumn{4}{|l|}{ FLAVANOIDS } \\
\hline $\begin{array}{l}\text { Alkaline reagent } \\
\text { test }\end{array}$ & $\begin{array}{l}\text { Intense yellow coloration that becomes colorless on addition of } \\
\text { dil.HCL }\end{array}$ & $\begin{array}{l}\text { Positive } \\
+\end{array}$ & $\begin{array}{l}\text { Positive } \\
+\end{array}$ \\
\hline Aqueous $\mathrm{FeCl}_{3}$ & Green blue/Blackish red coloration & $\begin{array}{l}\text { Positive } \\
+\end{array}$ & $\begin{array}{l}\text { Positive } \\
+\end{array}$ \\
\hline \multicolumn{4}{|l|}{ PHENOLS } \\
\hline Aq. $\mathrm{FeCl}_{3}$ Test & Deep blue/Black coloration & $\begin{array}{l}\text { Positive } \\
+\end{array}$ & $\begin{array}{l}\text { Positive } \\
+\end{array}$ \\
\hline Lead acetate Test & Formation of Bulky white precipitate & $\begin{array}{l}\text { Positive } \\
+\end{array}$ & $\begin{array}{l}\text { Positive } \\
+\end{array}$ \\
\hline \multicolumn{4}{|l|}{ GLYCOSIDE } \\
\hline $\begin{array}{l}\text { Keller Killiani } \\
\text { Test }\end{array}$ & Brown ring at the interface, Brown-greenish ring may form & $\begin{array}{l}\text { Positive } \\
+\end{array}$ & Negative \\
\hline Legal Test & Color changes t pink/red & $\begin{array}{l}\text { Positive } \\
+\end{array}$ & $\begin{array}{l}\text { Negative } \\
-\end{array}$ \\
\hline \multicolumn{4}{|l|}{ SAPONIN } \\
\hline Foam Test & Formation persistence foam & $\begin{array}{l}\text { Positive } \\
+\end{array}$ & $\begin{array}{l}\text { Negative } \\
-\end{array}$ \\
\hline \multicolumn{4}{|l|}{ CARBOHYDRATE } \\
\hline Molisch's Test & $\begin{array}{l}\text { Formation of red or dull violet color at the interface of the two } \\
\text { layers }\end{array}$ & $\begin{array}{l}\text { Positive } \\
+\end{array}$ & Negative \\
\hline \multicolumn{4}{|l|}{ TERPENOIDS } \\
\hline Salkowaski Test & Formation of reddish brown precipitate & $\begin{array}{l}\text { Positive } \\
+\end{array}$ & $\begin{array}{l}\text { Positive } \\
+\end{array}$ \\
\hline $\begin{array}{l}\text { Sulphuric acid } \\
\text { Test }\end{array}$ & Greenish blue coloration & $\begin{array}{l}\text { Positive } \\
+\end{array}$ & $\begin{array}{l}\text { Negative } \\
-\end{array}$ \\
\hline \multicolumn{4}{|l|}{ TANNINS } \\
\hline Braymer's Test & Formation of blue or greenish colour & $\begin{array}{l}\text { Positive } \\
+\end{array}$ & $\begin{array}{l}\text { Negative } \\
-\end{array}$ \\
\hline Lead acetate Test & Orange red precipitation or coloration & $\begin{array}{l}\text { Positive } \\
+\end{array}$ & Negative \\
\hline \multicolumn{4}{|l|}{ STEROIDS } \\
\hline $\begin{array}{l}\text { Liebermann- } \\
\text { Burchard Test }\end{array}$ & Formation of reddish brown precipitate & $\begin{array}{l}\text { Positive } \\
+\end{array}$ & $\begin{array}{l}\text { Negative } \\
-\end{array}$ \\
\hline Salkowaski Test & Formation of reddish brown precipitate & $\begin{array}{l}\text { Positive } \\
+\end{array}$ & $\begin{array}{l}\text { Positive } \\
+\end{array}$ \\
\hline \multicolumn{4}{|c|}{ AMINO ACID AND PROTEINS } \\
\hline Ninhydrin Test & Formation of purple color & $\begin{array}{l}\text { Positive } \\
+\end{array}$ & $\begin{array}{l}\text { Negative } \\
-\end{array}$ \\
\hline
\end{tabular}

Furthermore, exploration of antioxidants, carbohydrates and proteins were carried out. Keller Kiliani test on the sample extracts resulted in the formation of brown ring at the interface. While Legal test and Bontrager test showed change in pink or red colour and pinkish red colour of the ammonia layer confirming the presence of anthraquinone glycosides. Also test against Saponin and phenol presence and absence showed positive results as represented in Table 3 and Figure3. Similarly, the presence 
of Tannin was also tested during our research as tannin is also known for its beneficial anti-inflammatory effect. With the Braymer's test the formation of blue of greenish colour and Lead acetate test the formation of orange red precipitate indicated the presence of tannins. Gelatin test also confirmed the presence of tannins with white precipitate formation.
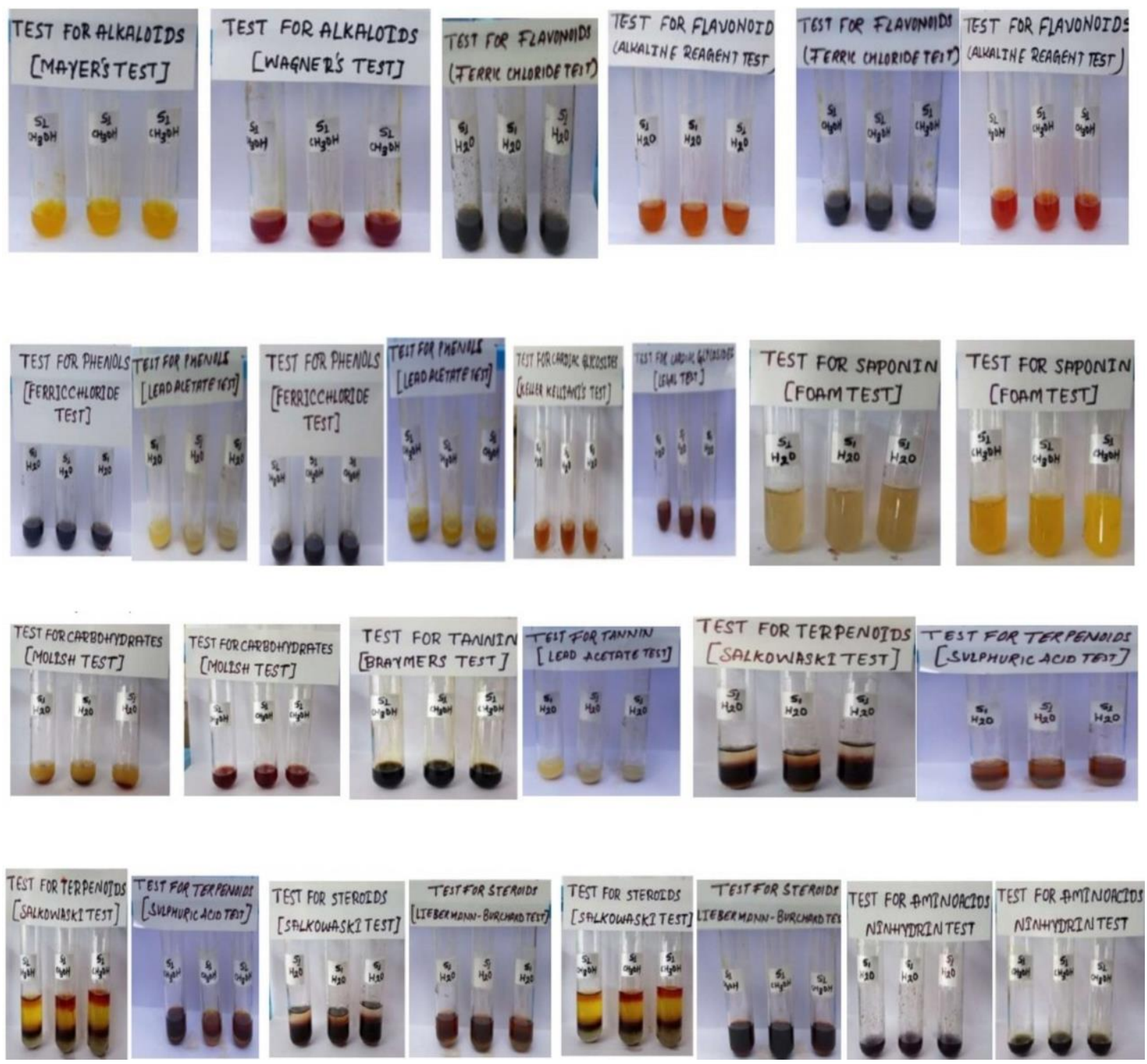

Figure 3: Phytochemical screening test for aqueous and methanolic extracts of Battisa.

The steroids and phytosterols also show essential medicinal properties that play beneficial role in maintaining health effects. So in our research we further proceeded to explore its presence or absence in battisa (polyherbal) with LiebermannBurchard test resulted in the appearance of greenish blue colouration indicated the presence of sterol and phytosterols. Cross validation test was also conducted with Salkowski test (Sulphuric acid test) showed the formation of reddish brown inter phase or reddish brown precipitate indicated the presence of sterol. Another vital antioxidant, flavonoids was confirmed with ferric chloride test with green blue colouration in both the extracts. Ninhydrin test was also conducted for the test for amino acids and proteins observed for the formation of purple colour showed positive results with aqueous extract while negative in methanolic extract may be get denatured in methanolic extract. Out of all the ten phytochemical quantitative tests five tests 
like alkaloids, flavonoids, phenols, terpenoids, steroids showed positive results with both aqueous as well as methanol based extracts. However, rest of the remaining tests resulted positive with aqueous extract only as shown in Table 3 and Figure 3.

\section{DISCUSSION}

The herbal composition of battisa constitutes of various antioxidants that has been reported to play beneficial medicinal properties and recovery nature for mother and newborn during postpartum period. This combinatorial composition from various medicinal plants acts as bioenhaners as well as immunomodulators. In India with traditional herbal medicine practice there is always been a culture of multiple combinatorial use of herbs. ${ }^{14}$ The phytochemical qualitative tests resulted the presence of alkanoids, flavanoids, phenols, terpenoids, steroids in both the extracts (methanol and aqueous). Various similar researches were observed with herbal plants with medicinal benifits. Out of all the ten phytochemical quantitative tests five tests like alkanoids, flavanoids, phenols, terpenoids, steroids showed positive results with both aqueous as well as methanol based extracts. However rest of the remaining tests resulted positive with aqueous extract only. Similar type of phytochemical analysis was carried out in medicinal plants Citrus paradisi which showed similar antioxidant presence of alkaloids, flavonoids, reducing sugars, Phenols, proteins, amino acids, saponins, tannins, terpenoids, and glycosides. It is also observed the presence of flavanoids, phenols, amino acids and terpenoids in different extracts of ethanol, aqueous and ethyl acetate. While in carbohydrates, saponins, tannins and glycosides were observed in ethanol and aqueous extract. ${ }^{15}$ Similar research of natural plant source lepidium pinnatifidum used in natural and synthetic drug also contained antioxidants found similar to our research.
The research showed the existence of terpenoids, flavonoids, phenols, tannins, proteins, saponins, alkaloids, betacyanin, anthocyanin, vitamin c, quinones, triterpenoids, and to some extent sterols, flavonoids, glycosides. ${ }^{16}$ It highlighted that the above respective compounds contain high medicinal characteristics like flavonoids having anti-cancerous properties, ${ }^{17}$ alkaloids possessing high antibacterial and analgesic properties, ${ }^{18}$ terpenoids with high anti-inflammatory, antibacterial, antiviral, anti-cancerous properties, ${ }^{19}$ phenol with antidibetic, antiinflammatory, antimicrobial, antimutagenic anti-cancerous properties. ${ }^{20}$, 21 Also saponins is widely used in the treatment of hypo cholesterol and hyperglycemia due to anticancer, antifungal, antibacterial properties. It is also used in weigh reduction. ${ }^{22}, 23$ Similar vital antioxidants positive phytochemical analysis in herbal composition of battisa helps in combating various immunological imbalances and provide health and nutritional support to mother and its new born during postpartum treatments.

\section{CONCLUSION}

The Phytochemical screening of extracts showed the presence of flavonoids, phenols, terpenoids, resulted in positive results in both aqueous and methanol solutions. While alkaloids, steroids, glycoside, amino acids and proteins showed positive results in one of the experimental extract solutions. These bioactive components showing positive results during experiments help in the recovery during postpartum period. This folk herbal formulation can be further subjected for antioxidant assay as it showed the presence of phenol and flavonoids. And this preliminary study will help in the awareness of scientific community along with human population to explore the beneficial role of herbal medicine towards postpartum period. 


\section{ACKNOWLEDGEMENT}

We sincerely thankful to Principal Marwari College Ranchi, Jharkhand, INDIA for availing facility for conducting research and Head Department of Tech. Biosciences, DIGIANALIX, South Samaj Street Tharpakhna, Ranchi, Jharkhand, INDIA for assisting in research.

\section{Conflict of Interest}

The authors declare no conflict of interest.

\section{Authors' Contribution}

SK, AKM did intensive research on various 'Exploring Insights of Battisa: A polyherbal formulation used during postpartum care' topics developed; SK contributed in writing the manuscript; ASK designed and supervised the present article and assisted in writing the paper.

\section{Source of Funding: None}

\section{Ethical Approval: Approved}

\section{REFERENCES}

1. Steinberg S. 1996. Childbearing research: a transcultural review. Social Science and Medicine 43, 1765-1784.

2. Blenning C.E. \& Paladine H. 2005. An approach to the postpartum office visit. American Family Physician 72, 2491-2498.

3. Mirmolaei T, A mell Valizadch $\mathrm{M}$, Matrommodi M, Tavakkoh, The effect of postpartum care at home on maternal received care and satisfaction. J.Nurs Midwifery care and satisfaction . J.Nurs Midwifery Mash had University. Med Sci. 2011, 35-48.

4. Jain Neelam, Ramawat G., Sharma Varsha , Therapeutic potential of medicinal plants traditionally used during postpartum period and their molecular targets. Journal of Ecobiotechnology , 3(10), 30-39,2011

5. Phillsbury BL. Doing the month confinement and convalescence in Chinese women after childbirth Soc . Sci . Med .12, 11-22, 1978.

6. Gunn J., Lumley J. \& Young D. 1998. Involvement of Victorian general practitioners in obstetric and postnatal care. Australian Family Physician 27, 73-83.

7. Roasting M.L. 2003. Smoking and Dieting: Malay Confinement in Cross-Cultural Perspective. In: The Manner Born: Birth Rites in Cross-Cultural Perspective (de L Dundes), pp. 137-159. Walnut Creek, CA: Altamira Press.

8. Piejko E. 2006. The postpartum visit--why wait 6 weeks?Australian Family Physician 35, 674-678.

9. Kim Godwin YS , postpartum beliefs and practices among non western cultures. MCN AM J. Matern Child Nurs, 28, 24-78, 2003.

10. Maffi L. 2005. Linguistic, cultural, and biological diversity. Annual Review of Anthropology 34, 599-617.

11. Harborne J, B. Phytochemical methods : A guide to modern technique of plant analysis 3rd edition, Chapman and Hall, New York, 1998

12. J.M. Sanchez, M. Hidalgo, V. Salvadó \& M. Valiente (1999) Extraction Of Neodymium (III) At Trace Level With Di(2-EthylHexyl) Phosphoric Acid In Hexane, Solvent Extraction and Ion Exchange, 17:3, 455474, DOI: 10.1080/07366299908934623.

13. FreitagH, Maier- Stole M, Kew Bull 35, 730,2003.

14. Atal C.K., Zutshi U. \& Rao P.G. 1981.Scientific evidence on the role of Ayurvedic herbals on Bioavailability of drug. Journal of Ethanopharmacology 4, 229-232.

15. Roghini R. and Vijayalakshmi K. 2018. Phytochemical screening, quantitative analysis of flavonoids and minerals in ethanolic extract of Citrus paradisi. IJPSR, 2018; Vol. 9(11): 4859-4864.

16. Hashmi HF, Bibi S, Anwar M, Khan MR. 2021. Qualitative and Quantitative Analysis of Phytochemicals in Lepidium pinnatifidum Ledeb. Scholars International Journal of Traditional and Complementary Medicine.

DOI: 10.36348/sijtcm.2021.v04i05.002

17. Yadav, R. N. S., \& Agarwala, M. (2011). Phytochemical analysis of some medicinal plants. Journal of phytology, 3.

18. Nassar Z, Aisha A, Abdul Majid A. The Pharmacological Properties Of Terpenoids From Sandoricum Koetjape. WebmedCentral Complementary Medicine 2010;1(12):WMC001311. 
19. Chung, K. T., Wong, T. Y., Wei, C. I., Huang, Y. W., \& Lin, Y. (1998). Tannins and human health: a review. Critical reviews in food science and nutrition, 38(6), 421-464.

20. Khan, M. K., Karnpanit, W., Nasar- Abbas, S. M., Huma, Z. E., \& Jayasena, V. (2015). Phytochemical composition and bioactivities of lupin: a review. International journal of food science \& technology, 50(9), 2004-2012.

21. Manjunatha, B., Antibacterial activity of Pterocarpus santalinus. Indian journal of pharmaceutical sciences 2006;68:115. Manjunatha, B. K. (2006). Antibacterial activity of Pterocarpus santalinus. Indian journal of pharmaceutical sciences, 68(1), 115.

22. Iloki-Assanga, S. B., Lewis-Luján, L. M., LaraEspinoza, C. L., Gil-Salido, A. A., Fernandez-Angulo, D., Rubio-Pino, J. L., Haines, D. D., Solvent effects on phytochemical constituent profiles and antioxidant activities, using four different extraction formulations for analysis of
Bucida buceras L. and Phoradendron californicum. BMC research notes 2015;8:396. Iloki-Assanga, S. B., LewisLuján, L. M., Lara-Espinoza, C. L., GilSalido, A. A., Fernandez-Angulo, D., Rubio-Pino, J. L., \& Haines, D. D. (2015). Solvent effects on phytochemical constituent profiles and antioxidant activities, using four different extraction formulations for analysis of Bucida buceras L. And Phoradendron californicum. BMC research notes, 8(1), 396.

23. Xiao, J. (2017). Dietary flavonoid aglycones and their glycosides: Which show better biological significance? Critical reviews in food science and nutrition, 57(9), 18741905.

How to cite this article: Kumari S, A.S. Khalkho. Exploring insights of battisa: a polyherbal formulation used during postpartum care. Int J Health Sci Res. 2022; 12(2): 96-104. DOI: https://doi.org/10.52403/ijhsr.20220213 